\title{
Vertical distribution of Microcystis colony size in Lake Taihu: Its role in algal blooms
}

Wei Zhu ${ }^{1,3}$, Ming $\mathrm{Li}^{2,4, *}$, Yonggang Luo ${ }^{1}$, Xiaoxuan $\mathrm{Dai}^{1}$, Lili Guo ${ }^{1}$, Man Xiao ${ }^{1}$,

$$
\text { Jingyu Huang }{ }^{1} \text {, Xiao Tan }{ }^{1}
$$

${ }^{1}$ College of Environment, Hohai University, No. 1 Xikang Road, Nanjing 210098, PR China

${ }^{2}$ College of Resources and Environment, Northwest A \& F University, Yangling 712100, PR China

${ }^{3}$ National Engineering Research Centre of Water Resources Efficient Utilization and Engineering Safety, Hohai University, Nanjing 210098, PR China

${ }^{4}$ Key Laboratory of Plant Nutrition and the Agri-environment in Northwest China, Ministry of Agriculture 
Abstract: This study investigated the vertical distributions of Microcystis cell density and colony size in Lake Taihu, where algal blooms occur frequently. Measurements were made from April 2011 to January 2012 to gain a seasonal outlook on the role of such distributions in the blooms. It was found that large colonies tended to accumulate on the water surface, but the cell density fluctuated widely. The cell density in the water column increased continuously from spring to summer (i.e., April to October) and decreased after late autumn, showing apparent seasonal variations. The abrupt occurrence and disappearance of Microcystis blooms over short periods of time was not caused by the rapid growth of Microcystis but by the rise and accumulation of large Microcystis colonies at the water surface, both of which are affected by colony size. The ascent velocity of large colonies was higher than that of small ones, which enables large colonies to more easily overcome the stirring effects of water flows, waves and perturbations to rise to the surface. The results of canonical correspondence analysis (CCA) of Microcystis vertical distribution in relation to environmental factors suggested that nutrient concentrations and temperature were the main influencing factors related to blooms formation by Microcystis in Lake Taihu during our investigation.

Keywords: Microcystis bloom, colony, rise and accumulation, vertical distribution 


\section{Introduction}

Cyanobacterial blooms in lakes and reservoirs, which are caused by eutrophication, bring about a series of environmental and ecological problems and can seriously threaten the safety of regional drinking water (Falconer, 2001; Le, 2010). The cyanobacterium Microcystis spp. is responsible for some of the most serious and widespread blooms in freshwaters.

The rise and accumulation of Microcystis on the water surface is one of the key mechanisms of bloom formation (Aparicio Medrano et al., 2013; Reynolds and Walsby, 1975; Verspagen et al., 2005). However, the patterns and factors that affect Microcystis vertical distributions are still poorly understood. Reynolds et al. (1973) showed that Microcystis colonies accumulated mainly in the upper $4 \mathrm{~m}$ of water from July to August in Crose Mere, England, and that the vertical distribution of Microcystis cell density fluctuates widely. Reynolds and Rogers (1976) also investigated seasonal variations in the vertical distribution and buoyancy of $M$. aeruginosa in Rostherne Mere, England, and found that Microcystis colonies stay on the surface of bottom sediments during winter, rise to the epilimnion in summer, and then sink back to the sediments in autumn. Both investigations indicate a seasonal variation in the vertical distribution and buoyancy of Microcystis. However, the mechanism of buoyancy regulation alone cannot explain the rapid changes in cell density in surface water layers and the different vertical distributions of Microcystis within the same season and environmental conditions. Thus, other factors aside from buoyancy must affect Microcystis accumulation on the water surface layer. 
Other researchers have focused on the effects of wind on the vertical distribution and accumulation of Microcystis on water surface layers. Takamura and Yasuno (1984) investigated the diurnal migration of five species, including $M$. aeruginosa, at the center of Takahamairi Bay in Lake Kasumigaura on a calm summer day and found that Microcystis colonies accumulated at the water surface in the early morning and then in the middle of the water column in the afternoon. Their records of the distribution of wind velocity at different times showed it to be high in the afternoon but low early in the morning. Thus, Microcystis colonies may be inferred to rise to the water surface under calm conditions and become re-entrained into the surface mixed layer with strong winds. Ha et al. (2000) studied the vertical distribution of Microcystis cell density in the Nakdong River (South Korea) during the summer of 1994 and found that Microcystis accumulated in the surface water layers during calm nights but was distributed uniformly in the water column during daytime, when strong winds and waves prevailed.

The effect of colony size on ascent velocities has also been studied. Kromkamp and Walsby (1990) investigated the buoyant density change rates of cyanobacteria in laboratory cultures and established a model to simulate diurnal changes in the buoyancy and vertical migration. This model suggested that large colonies experience more rapid vertical migrations. In addition, Wallace et al. (2000) investigated the vertical distribution of $M$. aeruginosa and established a model of buoyancy regulation. They found that the vertical distribution of $M$. aeruginosa depends on its carbohydrate content and colony size. Moreover, Wu and Kong (2009) investigated the vertical 
distribution of different colony sizes of M. aeruginosa in Lake Taihu and found that smaller colonies were more easily affected by wind-induced mixing than larger ones.

The studies discussed thus far confirm that vertical distribution of Microcystis is affected not only by the regulating mechanism of buoyancy but also by winds and waves. Colony size may influence the effect that wind has on the vertical distribution of Microcystis. As such, the relationship between the vertical distribution of cell density and colony size of Microcystis requires investigation to explain the mechanisms of vertical migration and bloom formation by Microcystis.

In this study, we investigated the vertical distribution of Microcystis cell density and colony size in Meiliang and Gonghu Bays in Lake Taihu, where Microcystis blooms occur frequently. We also investigated the relationships between Microcystis blooms, colony size and environmental factors. The findings obtained helped increase our understanding of mechanisms controlling Microcystis blooms.

\section{Materials and Methods}

\section{Study site description}

Sampling was carried out in two bays within the northern region of Lake Taihu, namely, Meiliang Bay and Gonghu Bay. Six sampling sites were established in the middle of the two bays (Figure 1).

[Insert Fig. 1 here]

\section{Sampling and analytical methods}




\section{Sampling}

The study period was from April 2011 to January 2012. Sampling was carried out twice a month from April 2011 to October 2011 and then once a month for the rest of the study period. Since the depths of sites were about $2 \mathrm{~m}, 100 \mathrm{~mL}$ of water was collected from the bottom to the water surface at $0.5 \mathrm{~m}$ intervals using a polymethyl methacrylate sampler (Finucane and May, 1961) for Microcystis cell density and colony size analysis. Formalin $(2 \%(\mathrm{v} / \mathrm{v}))$ was immediately added to the samples for subsequent cell counting and colony size analysis. At each site, water temperature and $\mathrm{pH}$ was measured in the field using an electronic thermometer (Mettler SG7) and compact $\mathrm{pH}$ meter ( $\mathrm{pH}$ Testr30), respectively. Equal volumes of water collected at both the surface and a depth of $1.0 \mathrm{~m}$ below the surface were mixed in a $500 \mathrm{~mL}$ plastic bottle. It was kept refrigerated and carried to the laboratory for chemical analysis. The information of wind speed and direction was collected from a meteorological station (see Fig. 1; Ding et al. 2012).

Chemical analysis: Water samples for chemical analysis were filtered through a 0.45 $\mu \mathrm{m}$ pore size membrane and the filtrate was used to analyze for total dissolved nitrogen (TDN) and total dissolved phosphorus (TDP) concentrations. The TDN and TDP concentrations were analyzed by colorimetry after digestion with $\mathrm{K}_{2} \mathrm{~S}_{2} \mathrm{O}_{8}+\mathrm{NaOH}$ (Ebina et al., 1983).

\section{Cell counting}

A sample of $3 \mathrm{~mL}$ was placed into a centrifuge tube $(10 \mathrm{~mL})$. The centrifuge tube was 
then placed in a $100{ }^{\circ} \mathrm{C}$ water-bath oscillator and shaken at $120 \mathrm{rpm}$ for 5 min (Joung et al., 2006). Finally, cells were counted three times in a blood cell counting chamber using an optical microscope (Olympus CX31; Olympus Corporation) at $\times 400$ magnification, after which the cell density was calculated. If the difference between three calculated results was less than $10 \%$, the average value of these results was used as the final estimate of the cell density; otherwise an additional count was carried out.

\section{Colony size analysis}

Sample remaining was shaken and examined using the optical microscope (Olympus CX31) at $\times 100$ magnification. Photomicrographs were taken using an optical C-5050 digital camera, and the colony size of Microcystis was directly analyzed using the UTHSCSA ImageTool program version 3 (Wilcox et al., 2002). A minimum of 200 colonies per sample was counted to calculate the $\mathrm{D}_{50}$ (signifying where $50 \%$ of the particles are smaller than the value of $\mathrm{D}_{50} ; \mathrm{D}$ is particle diameter) of the Microcystis colony size; the $\mathrm{D}_{50}$ was used to indicate the average size of algal colonies.

\section{Statistical analyses}

The average cell density in the water column was calculated as follows:

$$
\mathrm{C}_{\text {Average }}=\left(\mathrm{C}_{0 \mathrm{~m}} \times \mathrm{h}_{1}+\mathrm{C}_{0.5 \mathrm{~m}} \times \mathrm{h}_{2}+\mathrm{C}_{1.0 \mathrm{~m}} \times \mathrm{h}_{3}+\mathrm{C}_{1.5 \mathrm{~m}} \times \mathrm{h}_{4}+\mathrm{C}_{2.0 \mathrm{~m}} \times \mathrm{h}_{5}\right) / 2
$$

where $\mathrm{C}_{\text {Average }}$ is the average cell density of Microcystis in the water column, $\mathrm{C}_{\mathrm{i}}$ is the cell density of Microcystis at the depth $\mathrm{i}$, and $\mathrm{h}_{\mathrm{i}}$ is the height of the water column at depth $\mathrm{i}\left(\mathrm{h}_{1}\right.$ and $\mathrm{h}_{5}$ were both $0.25 \mathrm{~m} ; \mathrm{h}_{2}, \mathrm{~h}_{3}$ and $\mathrm{h}_{4}$ were all $\left.0.5 \mathrm{~m}\right)$. 
Canonical correspondence analysis (CCA) was applied to reveal relationships between environmental factors and $\mathrm{C}_{0-0.25 \mathrm{~m}} / \mathrm{C}_{0-2.0 \mathrm{~m}}$. The CCA was performed with the software CANOCO 4.5 (SCIENTIA Software).

\section{Results}

\section{Environmental parameters}

Water temperature increased gradually from April to August and then decreased (Fig.

2). The maximum and minimum of water temperature during the investigation was $31.0^{\circ} \mathrm{C}$ in mid-August and $4.9^{\circ} \mathrm{C}$ in January. The $\mathrm{pH}$ values fluctuated in the range of 7.5 to 8.5 and were low (below 8) from August to October.

[Insert Fig. 2 here]

The maximum TDN concentration of $4.56 \mathrm{mg} / \mathrm{L}$ was measured in August whereas the maximum TDP concentration $(0.371 \mathrm{mg} / \mathrm{L})$ was measured in October (Fig. 3). The minimum values of TDN and TDP were $0.15 \mathrm{mg} / \mathrm{L}$ and $0.001 \mathrm{mg} / \mathrm{L}$, respectively. TDP was sufficient in summer but nearly depleted during fall.

[Insert Fig. 3 here]

Table 1 shows wind speed and direction obtained from the meteorological station from April to October 2011. The average wind speed was in the range of 1.7 to 2.9 $\mathrm{m} / \mathrm{s}$ and the wind direction was primarily eastern. The maximum wind speed was 6.3 $\mathrm{m} / \mathrm{s}$ on $1^{\text {st }}$ May.

[Insert Table 1 here] 


\section{Vertical distribution of Microcystis cell density}

The cell density at the water surface was generally higher than that below the surface at all sampling sites and 2 to 3 times higher than the average value in the water column (Fig. 4). From August to October, when Microcystis blooms occur frequently, the cell density at the surface was over $5 \times 10^{8}$ cells/L, reflecting the intense accumulation of biomass at the surface during the bloom. Instances when the cell density near the bottom was comparable to that at the water surface occurred occasionally. For example, all cell densities at different depths in site 1 on August 11 were in the range $5 \times 10^{8}$ to $7 \times 10^{8}$ cells/L; only minor fluctuations in cell density were observed at this time.

The cell density at the water surface was observed to fluctuate strongly whereas the cell density below the surface showed only slight fluctuations. The cell density in the top $0.5 \mathrm{~m}$ was higher than the average value in the water column, whereas the cell density at depths greater than $1.0 \mathrm{~m}$ was generally lower than the average value.

The average cell density in the water column in Meiliang Bay was about $4 \times 10^{8}$ cells/ $\mathrm{L}$ while that in Gonghu Bay was only about $3 \times 10^{8}$ cells/L. In addition, the maximum cell density in the water surface was $8 \times 10^{8}$ to $10 \times 10^{8}$ cells/L in Meiliang Bay whereas it was $7 \times 10^{8}$ to $9 \times 10^{8}$ cells/L in Gonghu Bay.

[Insert Fig. 4 here]

The average cell density in the water column showed obvious seasonal variations (solid line in Fig. 4). The average cell density in the water column increased 
continuously from April, showed maximum values from September to October, and then decreased from November onwards.

\title{
Vertical distribution of Microcystis colony size
}

The size of Microcystis colonies increased from April to October and then decreased thereafter (Fig. 5). The $\mathrm{D}_{50}$ of Microcystis colony size was about $20 \mu \mathrm{m}$ to $50 \mu \mathrm{m}$ in spring, increased to $>200 \mu \mathrm{m}$ by October, and then showed a gradual decrease from November onwards.

The colony size of Microcystis at the water surface fluctuated widely, and the $\mathrm{D}_{50}$ of Microcystis colony size ranged from $50 \mu \mathrm{m}$ to $700 \mu \mathrm{m}$. The colony size of Microcystis at depths of $0.5 \mathrm{~m}$ and $1.0 \mathrm{~m}$ also fluctuated, but the $\mathrm{D}_{50}$ of Microcystis colony size at these depths was below $200 \mu \mathrm{m}$. The colony size of Microcystis at depths greater than $1.0 \mathrm{~m}$ fluctuated slightly, and its $\mathrm{D}_{50}$ was mostly below $100 \mu \mathrm{m}$.

\author{
[Insert Fig. 5 here]
}

\section{Discussion}

\section{Vertical distribution patterns of Microcystis cell density and colony size}

\section{Cell density}

The vertical distribution of Microcystis cell density can be concluded to show four patterns (Fig. 6a). In the growth and decline phases, cell densities were uniformly low throughout the water column (Fig. 6a, pattern I). Three patterns can be found in the bloom phase (Fig. 6a, patterns II, III, and IV). In pattern II, most of the Microcystis 
colonies accumulate at the surface, causing the cell density at other depths to decrease. In pattern III, high cell densities of Microcystis are distributed uniformly through the water column whereas in pattern IV, cell density declines gradually from the surface.

\section{Colony size}

Four patterns of vertical distribution of Microcystis colony size corresponding to the four patterns of Microcystis vertical distribution of cell density are shown in Fig. 6b. The $\mathrm{D}_{50}$ of colony size distributes uniformly in the water column in patterns $\mathrm{A}$ and $\mathrm{C}$, with a colony size threshold of $100 \mu \mathrm{m}$ distinguishing between the two patterns. In pattern $\mathrm{B}$, the $\mathrm{D}_{50}$ at the water surface is high (about $500 \mu \mathrm{m}$ ), whereas the values at other depths are low and distribute uniformly through the water column. Pattern D shows the same regularity of distribution as in pattern $B$, but its $D_{50}$ is about $200 \mu \mathrm{m}$ at the water surface.

[Insert Fig. 6 here]

\section{Relationship between the vertical distribution of cell density and colony size of Microcystis}

Our investigation showed that a water column profile of uniformly low Microcystis cell density (pattern I) corresponded to pattern A in terms of colony size distribution. Under this condition, the cell density and colony size at different depths showed no discernible differences. In the growth phase (before May), the small Microcystis colonies that form cannot readily rise and accumulate on the water surface.

From May to October, the cell densities at different depths increased noticeably and 
the colony size in the water column also increased. Patterns II, III, and IV of the vertical distribution of cell density corresponded to patterns $\mathrm{B}, \mathrm{C}$, and $\mathrm{D}$ of the vertical distribution of colony size, respectively. In the decline phase, slight changes were observed.

\section{Roles of growth and colony rise and accumulation on the water surface in}

\section{Microcystis blooms}

The average Microcystis cell density in the unit water column is used here to show the growth in the water column. The average water column cell density of Microcystis in September was ten times higher than that in April. Moreover, the cell density at the water surface was ten times higher than that below the water in the bloom phase. The increase in total cell number is due to the growth of the Microcystis population. However, our study indicated that growth alone cannot bring about rapid bloom formation. The cell density at the water surface rises and falls rapidly because of vertical migration of Microcystis colonies. Accumulation of most of the colonies at the water surface could lead to Microcystis blooms even if the total cell number in the water column is not high (Site 6 on July 4). Sometimes (Site 3 on August 11), the cell density at the water surface was similar to the average value in the water column from the surface to a depth of $0.25 \mathrm{~m}$ but it was observed (data are not shown in the current study) that most of the colonies would accumulate as a very thin layer (only several millimeters) on the water surface. When this occurs (similar to telescoping defined by Reynolds and Walsby (1975)), the cell density in the thin layer may be hundreds of times larger than that observed below the layer. Bloom formation can thus be 
concluded to be directly caused by the rapid rise and accumulation of Microcystis colonies, not by their growth.

Our results also showed that the cell density distribution is related to the colony size of Microcystis. Nakamura et al. (1993) determined the rising velocity of Microcystis colonies of different sizes using a microscopic video camera and recorder and found that the rising velocity of colonies $100 \mu \mathrm{m}$ in size is $30 \mu \mathrm{m} / \mathrm{s}$ whereas that of colonies $400 \mu \mathrm{m}$ in size is $300 \mu \mathrm{m} / \mathrm{s}$. Stokes' law describes the vertical migration velocity as follows: $\mathrm{v}=\mathrm{kg} \mathrm{D}^{2}\left(\rho-\rho_{\text {water }}\right) / 18 \mu$ where $\mathrm{v}$ is the vertical migration velocity, $\mathrm{k}$ is fractal coefficient, $g$ is acceleration due to gravity, D is particle diameter, $\rho$ is particle density, $\rho_{\text {water }}$ is density of water, $\mu$ is viscosity of surrounding liquid. If we assume $\rho$ of Microcystis colonies to be constant and smaller than $\rho_{\text {water, }}$ the floating velocity of a $200 \mu \mathrm{m}$ colony would be 100 times higher than that of a $20 \mu \mathrm{m}$ colony. In calm weather, when colonies have adequate buoyancy, large colonies may rise swiftly to the water surface and form blooms.

\section{Roles of colony size in Microcystis blooms}

The $\mathrm{D}_{50(0 \mathrm{~m})} / \mathrm{D}_{50(1.0 \mathrm{~m})}$ can reflect the separation of colony size in the water column, where $\mathrm{D}_{50(0 \mathrm{~m})}$ is the $\mathrm{D}_{50}$ of Microcystis colony size at the water surface and $\mathrm{D}_{50(1.0 \mathrm{~m})}$ is the $\mathrm{D}_{50}$ of Microcystis colony size at $1.0 \mathrm{~m}$ below the water surface. In this study, $\mathrm{C}_{0-0.25 \mathrm{~m}} / \mathrm{C}_{0-2.0 \mathrm{~m}}$ was used to indicate the separation of cell number in the water column; $\mathrm{C}_{0-0.25 \mathrm{~m}}$ is the cell number in the column from the surface to $0.25 \mathrm{~m}$ below the water surface and $\mathrm{C}_{0-2.0 \mathrm{~m}}$ is the total cell number in the whole water column. If Microcystis 
is distributed uniformly in the water column, $\mathrm{C}_{0-0.25 \mathrm{~m}} / \mathrm{C}_{0-2.0 \mathrm{~m}}$ would be about $12.5 \%$. Fig. 7a shows data obtained for the six sites in this study; $\mathrm{D}_{50(0 \mathrm{~m})}$ in different ranges (100 $\mu \mathrm{m}$ intervals) is also marked with different graphic symbols. When $\mathrm{D}_{50(0}$ m) $/ \mathrm{D}_{50(1.0 \mathrm{~m})}$ was less than $1, \mathrm{C}_{0-0.25 \mathrm{~m}} / \mathrm{C}_{0-2.0 \mathrm{~m}}$ was generally below $12.5 \%$ and $\mathrm{D}_{50(0 \mathrm{~m})}$ was less than $100 \mu \mathrm{m}$. Excluding $\mathrm{D}_{50(0 \mathrm{~m})}<100 \mu \mathrm{m}, \mathrm{C}_{0-0.25 \mathrm{~m}} / \mathrm{C}_{0-2.0 \mathrm{~m}}$ increased linearly

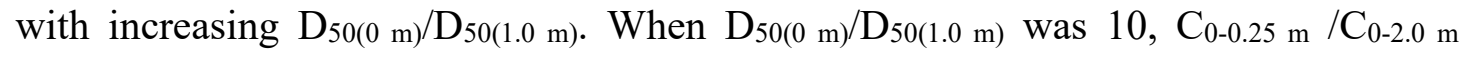
reached nearly $50 \%$. Moreover, when $\mathrm{D}_{50(0 \mathrm{~m})} / \mathrm{D}_{50(1.0 \mathrm{~m})}$ was $100, \mathrm{C}_{0-0.25 \mathrm{~m}} / \mathrm{C}_{0-2.0 \mathrm{~m}}$ reached nearly $80 \%$, suggesting that accumulation of Microcystis on the water surface is related to the separation of the colony size in the water column. When obvious separation of colony size in the water column and accumulation of Microcystis at the surface occurred, $\mathrm{D}_{50(0 \mathrm{~m})}$ was higher than $100 \mu \mathrm{m}$ (mainly ranging from $200 \mu \mathrm{m}$ to $400 \mu \mathrm{m})$. Therefore, we can conclude that colonies larger than $100 \mu \mathrm{m}$ rise rapidly to the water surface and form blooms more easily than small ones.

\section{[Insert Fig. 7 here]}

Fig. $7 \mathrm{~b}$ shows that when $\mathrm{D}_{50(0 \mathrm{~m})} / \mathrm{D}_{50(1.0 \mathrm{~m})}$ ranged from 1 to 10 , the cell density at the surface was about $5 \times 10^{8}$ to $10 \times 10^{8}$ cells/L, indicating that Microcystis blooms occurred at the surface.

The discussion above strongly suggests that the rise and accumulation of Microcystis colonies on the water surface is the main mechanism of Microcystis bloom formation. Accumulation is affected by the colony size of Microcystis; large colonies easily rise and accumulate on the water surface, whereas small colonies encounter more 
difficulty rising to the water surface due to the effects of winds and waves. Water in lakes is affected by the wind and tides, and flows, waves, and disturbances are ever-present in the lake, stirring colonies continuously. The rising velocity of large colonies is larger than that of small ones; this velocity helps large colonies overcome the stirring effects of flows, waves, and disturbances. Small colonies cannot overcome these effects; thus, they cannot rise to the water surface.

\section{Effects of environmental factors on vertical distribution of Microcystis colonies}

Figure 8 shows canonical correspondence analysis (CCA) ordination diagram of $\mathrm{C}_{0-0.25 \mathrm{~m}} / \mathrm{C}_{0-2.0 \mathrm{~m}}$ in relation to environmental factors. The two axes accounted for $79.9 \%$ of observed variation of the species-environment relationship (the first and second axis explained $47.8 \%$ and $32.0 \%$, respectively). It was also obvious that $\mathrm{C}_{0-0.25}$ $\mathrm{m} / \mathrm{C}_{0-2.0 \mathrm{~m}}$ was negatively related to wind speed, TDN, temperature, $\mathrm{pH}$ and TDN: TDP ratio when $\mathrm{D}_{50}$ of Microcystis at the water surface was in range of 100 to $400 \mu \mathrm{m}$. However, when $\mathrm{D}_{50}$ of Microcystis at the water surface was larger than $400 \mu \mathrm{m}, \mathrm{C}_{0-0.25}$ $\mathrm{m} / \mathrm{C}_{0-2.0 \mathrm{~m}}$ was positively related to TDP. Nevertheless, $\mathrm{C}_{0-0.25 \mathrm{~m}} / \mathrm{C}_{0-2.0} \mathrm{~m}$ positively related to all the environmental factors while $\mathrm{D}_{50}$ of Microcystis at water surface was smaller than $100 \mu \mathrm{m}$. Regardless of size, no significant difference was found between $\mathrm{C}_{0-0.25 \mathrm{~m}} / \mathrm{C}_{0-2.0 \mathrm{~m}}$ and environmental factors.

High wind speed is expected to promote mixing making Microcystis colonies distribute uniformly in the water column (Wu et al., 2013). The phenomenon that $\mathrm{C}_{0-0.25 \mathrm{~m}} / \mathrm{C}_{0-2.0 \mathrm{~m}}$ was negatively related to wind speed was a good interpretation of the 
effects of wind speed.

The buoyancy of Microcystis colonies is dependent upon their gas vesicle volume and carbohydrate metabolism (Thomas and Walsby, 1985). High light intensity would induce collapse of gas vesicles and increase carbohydrate ballast, both of which promote sinking of Microcystis colonies (Ibelings et al., 1991). However, massive Microcystis blooms occurred during our investigation in summer and autumn when the light intensity was high (although light intensity was not measured in 2011, instantaneous light intensity was recorded as 400 to $1000 \mu \mathrm{mol} \cdot \mathrm{photons} /\left(\mathrm{m}^{2} \cdot \mathrm{s}\right)$ during the same sampling process in 2012; Li et al., 2014). Moreover, most colonies collected at different depths were floating at the water surface in the bottles when they were taken back to the laboratory. This suggests that the buoyancy of Microcystis colonies was sufficient to float to the water surface. Therefore, light intensity was not the main influencing factor related to blooms formation of Microcystis in Lake Taihu during our investigation.

Laboratory experiments demonstrated that gas vesicle volume per cell of Microcystis decreased significantly during nitrogen-limited growth but decreased only slightly during phosphorus-limited growth (Chu et al., 2007). However, Brooks and Ganf (2001) illustrated that Microcystis cells growing in $1.2 \mathrm{mg} / \mathrm{L} \mathrm{N}$ and $0.31 \mathrm{mg} / \mathrm{L} \mathrm{P}$ increased their gas vesicle volume and retained positive buoyancy. Fig. 3 showed that TDN concentrations in Lake Taihu were more than $1.2 \mathrm{mg} / \mathrm{L}$ most of the time, but TDP concentrations were always below than $0.31 \mathrm{mg} / \mathrm{L}$. Thus, neither $\mathrm{N}$ nor $\mathrm{P}$ could be the limiting factors influencing formation of gas vesicle of Microcystis colonies in 
Lake Taihu in the current study. However, those results were obtained from laboratory experiments in which unicellular or small colonial Microcystis was used (Brooks and Ganf, 2001) and we cannot make assumptions on the nutrient status of the cell based on measured nutrient levels without knowledge of cellular nutrient stoichiometry. Fig. 8 showed that $\mathrm{C}_{0-0.25 \mathrm{~m}} / \mathrm{C}_{0-2.0} \mathrm{~m}$ positively related to TDP while $\mathrm{D}_{50}$ of Microcystis at the water surface was larger than $400 \mu \mathrm{m}$ and positively related to TDN while $\mathrm{D}_{50}$ of Microcystis at the water surface was smaller than $100 \mu \mathrm{m}$. It was also suggested that the decreasing $\mathrm{P}$ concentration resulted in a rise of Microcystis colonies smaller than $400 \mu \mathrm{m}$ and decreasing $\mathrm{N}$ concentration caused a rise of Microcystis colonies larger than $100 \mu \mathrm{m}$. Our recent study also showed that the effects of nutrient concentrations on the growth of Microcystis in Lake Taihu was size-dependent. Thus, the effects of nutrient concentrations on changes in buoyancy of different sized Microcystis colonies should be studied in the future.

$\mathrm{C}_{0-0.25 \mathrm{~m}} / \mathrm{C}_{0-2.0 \mathrm{~m}}$ positively related to temperature while $\mathrm{D}_{50}$ of Microcystis at the water surface was smaller than $200 \mu \mathrm{m}$ (Fig. 8). However, the relationship between $\mathrm{C}_{0-0.25}$ $\mathrm{m} / \mathrm{C}_{0-2.0} \mathrm{~m}$ and $\mathrm{D}_{50}$ of Microcystis was negative while $\mathrm{D}_{50}$ of Microcystis at water surface was larger than $200 \mu \mathrm{m}$. These results showed that high temperature was in favour of positive buoyancy of small Microcystis colonies. This could be because carbohydrate ballast of Microcystis colonies decreased at high temperature (Thomas and Walsby, 1986; Visser et al., 1995).

This study found that the vertical distribution of cell density was closely correlated with colony size, with the bloom mainly composed of large colonies. This suggests a 
different explanation of bloom formation from the previous buoyancy regulation by cell metabolism. This could certainly be a future research topic to elucidate what controls the colony size so as to affect the accumulation. Future investigations will be aimed toward identifying factors that control colony size in bloom-forming Microcystis.

Acknowledgments: This study was sponsored by the National Program on Key Basic Research Project of China (No. 2012CB719804), the Natural Science Foundation of Jiangsu Province (No. SBK2011025) and the Hydraulic Science \& Technology Project of Jiangsu Province (2012012).

\section{References}

Aparicio Medrano, E., Uittenbogaard, R., Dionisio Pires, L., van de Wiel, B., Clercx, H. 2013, Coupling hydrodynamics and buoyancy regulation in Microcystis aeruginosa for its vertical distribution in lakes. Ecol. Model. 248: 41-56.

Brookes, J.D., Ganf, G.G., 2001, Variations in the buoyancy response of Microcystis aeruginosa to nitrogen, phosphorus and light. J. Plankton Res. 23, 1399-1411.

Chu, Z., Jin, X., Yang, B., Zeng, Q., 2007, Buoyancy regulation of Microcystis flos-aquae during phosphorus-limited and nitrogen-limited growth. J. Plankton Res. 29, 739-745.

Ding Y, Qin B, Zhu G, Wu T, Wang Y, Luo L. 2012. Effects of typhoon Morakot on a large shallow lake ecosystem, Lake Taihu, China. Ecohydrology 5, 798-807.

Ebina J, Tsutsui T, Shirai T. 1983. Simultaneous determination of total nitrogen and 
total phosphorus in water using peroxodisulfate oxidation. Water Res. 17: 1721-1726.

Falconer, I.R., 2001, Toxic cyanobacterial bloom problems in Australian waters: risks and impacts on human health. Phycologia 40, 228-233.

Finucane, J.H., May, B.Z., 1961, Modified van Dorn water sampler. Limnol. Oceanogr. 6, 85-87.

Ha, K., Kim, H.W., Jeong, K.S., Joo, G.J., 2000, Vertical distribution of Microcystis population in the regulated Nakdong River, Korea. Limnology 1, 225-230.

Ibelings, B.W., Mur, L.R., Walsby, A.E., 1991, Diurnal changes in buoyancy and vertical distribution in populations of Microcystis in two shallow lakes. J. Plankton Res. 13, 419-436.

Joung, S.H., Kim, C.J., Ahn, C.Y., Jang, K.Y., Boo, S.M., Oh, H.M., 2006, Simple method for a cell count of the colonial cyanobacterium, Microcystis sp. J. Microbiol. $44,562-565$.

Kromkamp, J., Walsby, A.E., 1990, A computer model of buoyancy and vertical migration in cyanobacteria. J. Plankton Res. 12, 161-183.

Le, C., Zha, Y., Li, Y., Sun, D., Lu, H., Yin, B., 2010, Eutrophication of Lake Waters in China: Cost, Causes, and Control. Environ. Manage. 45, 662-668.

Li, M., Zhu, W., Dai, X., Xiao, M., Appiah-Sefah, G., Nkrumah, P.N., 2014, Size-dependent growth of Microcystis colonies in a shallow, hypertrophic lake: use of the RNA-to-total organic carbon ratio. Aquat. Ecol. 48, 207-217. 
Nakamura, T., Adachi, Y., Suzuki, M., 1993, Flotation and sedimentation of a single Microcystis floc collected from surface bloom. Water Res. 27, 979-983.

Reynolds, C., 1973, Growth and buoyancy of Microcystis aeruginosa Kütz. emend. Elenkin in a shallow eutrophic lake. P. Roy. Soc. B - Biol. Sci. 184, 29-50.

Reynolds, C.S., Walsby, A., 1975, Water-blooms. Biol. Rev. 50, 437-481.

Reynolds, C., Rogers, D., 1976, Seasonal variations in the vertical distribution and buoyancy of Microcystis aeruginosa Kütz. emend. Elenkin in Rostherne Mere, England. Hydrobiologia 48, 17-23.

Takamura, N., Yasuno, M., 1984, Diurnal changes in the vertical distribution of phytoplankton in hypertrophic Lake Kasumigaura, Japan. Hydrobiologia 112, 53-60.

Thomas, R., Walsby, A., 1985, Buoyancy regulation in a strain of Microcystis. J. Gen. Microbiol. 131, 799-809.

Visser, P.M., Ibelings, B.W., Mur, L.R., 1995, Autunmal sedimentation of Microcystis spp. as result of an increase in carbohydrate ballast at reduced temperature. J. Plankton Res. 17, 919-933.

Verspagen, J.M.H., Snelder, E.O.F., Visser, P.M., Jöhnk, K.D., Ibelings, B.W., Mur, L.R., Huisman, J., 2005, Benthic-pelagic coupling in the population dynamics of the harmful cyanobacterium Microcystis: Freshwater Biol. 50, 854-867.

Wallace, B.B., Bailey, M.C., Hamilton, D.P., 2000, Simulation of vertical position of buoyancy regulating Microcystis aeruginosa in a shallow eutrophic lake. Aquat. Sci. $62,320-333$. 
Wilcox, D., Dove, B., McDavid, D., Greer, D., 2002, UTHSCSA image tool for windows v 3.00. The University of Texas Health Science Centre, San Antonio.

Wu, T., Qine B., Zhu, G., Luo, L., Ding, Y., Bian, G., 2013, Dynamics of cyanobacterial bloom formation during short-term hydrodynamic fluctuation in a large shallow, eutrophic, and wind-exposed Lake Taihu, China. Environ. Sci. Pollut. R. 20, 8546-8556.

Wu, X., Kong, F., 2009, Effects of light and wind speed on the vertical distribution of Microcystis aeruginosa colonies of different sizes during a summer bloom. Int. Rev. Hydrobiol. 94, 258-266.

Table 1 Wind speed and direction in Lake Taihu from April to October 2011

\begin{tabular}{cccc}
\hline & \multicolumn{2}{c}{ Wind speed $(\mathbf{m} / \mathbf{s})$} & $\begin{array}{c}\text { Wind } \\
\text { Direction }\end{array}$ \\
\cline { 2 - 3 } 17-Apr & 2.30 & 5.40 & $\mathrm{NE}$ \\
1-May & 2.50 & 6.30 & $\mathrm{E}$ \\
17-May & 1.70 & 4.90 & $\mathrm{~S}$ \\
4-Jun & 2.10 & 3.80 & $\mathrm{SE}$ \\
14-Jun & 2.60 & 5.80 & $\mathrm{E}$ \\
4-Jul & 2.30 & 5.00 & $\mathrm{~N}$ \\
18-Jul & 2.30 & 4.00 & $\mathrm{E}$ \\
29-Jul & 2.60 & 4.70 & $\mathrm{~S}$ \\
\hline 11-Aug & 1.80 & 5.80 & $\mathrm{NE}$ \\
1-Sep & 2.60 & 4.30 & $\mathrm{NE}$ \\
\hline 17-Sep & 2.00 & 6.10 & $\mathrm{~N}$ \\
1-Oct & 2.90 & 5.40 & $\mathrm{NE}$ \\
\hline
\end{tabular}


1 Figure captions:

2 Fig. 1 Sampling sites in Meiliang Bay and Gonghu Bay in Lake Taihu, China. The

3 insert in the figure describes the location of the sampling area in Lake Taihu.

4 Fig. 2 Seasonal variation of average water temperature and $\mathrm{pH}$ of all the six sites in $5 \quad$ Lake Taihu.

6 Fig. 3 The TDN and TDP concentrations at different sites in different months.

7 Fig. 4 Seasonal variation in Microcystis cell density at different depths.

8 Fig. 5 Seasonal variation in the $\mathrm{D}_{50}$ of Microcystis colony sizes at different depths.

9 Fig. 6 Vertical distribution patterns of Microcystis (a) cell density and (b) colony size. I: growth and decline phase; II, III and IV: different patterns of bloom phase.

Fig. 7 Relationships between colony size separation, cell density separation, and cell density in the water surface: (a) Relationship between colony size separation and cell density separation and (b) relationship between colony size separation and cell density in the water surface. The dashed line shows the linear regression trendline of the data of which $\mathrm{D}_{50(0 \mathrm{~m})}$ was larger than $100 \mu \mathrm{m}$.

Fig. 8 Canonical correspondence analysis (CCA) ordination diagram of $\mathrm{C}_{0-0.25}$

$17 \mathrm{~m} / \mathrm{C}_{0-2.0 \mathrm{~m}}$ in relation to environmental factors 




[Fig. 1]

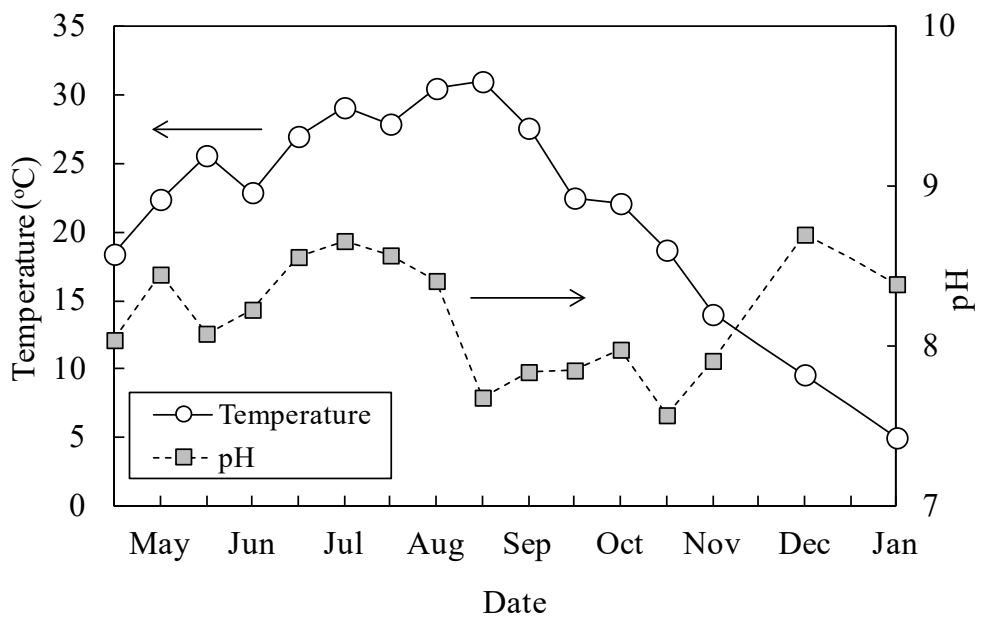

[Fig. 2] 

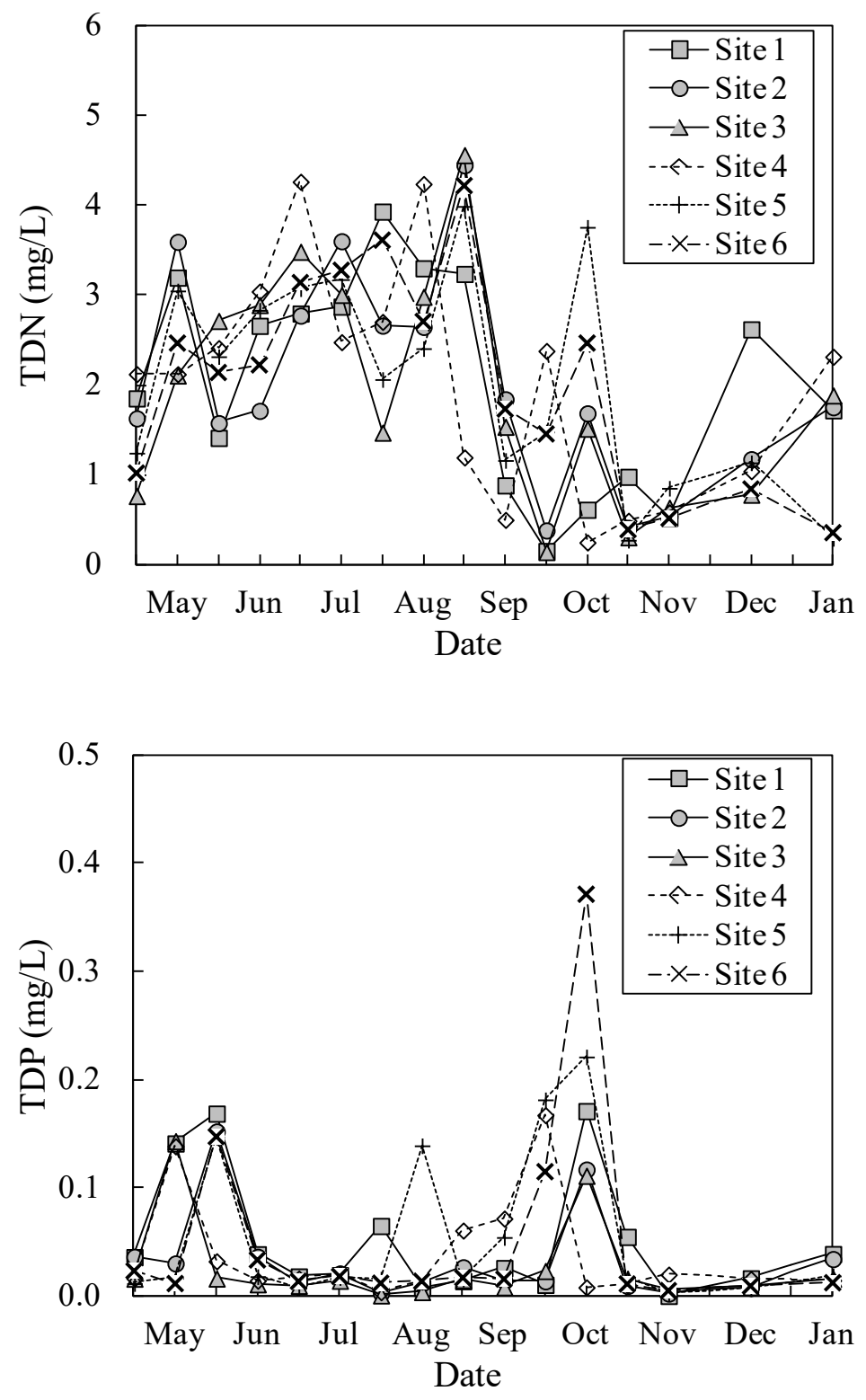

[Fig. 3] 


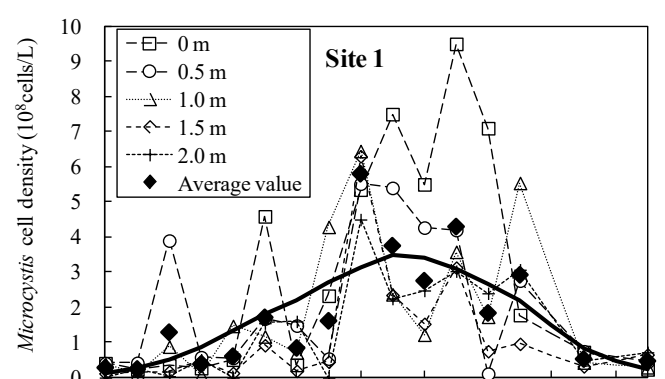

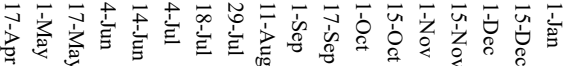
Date



42

43

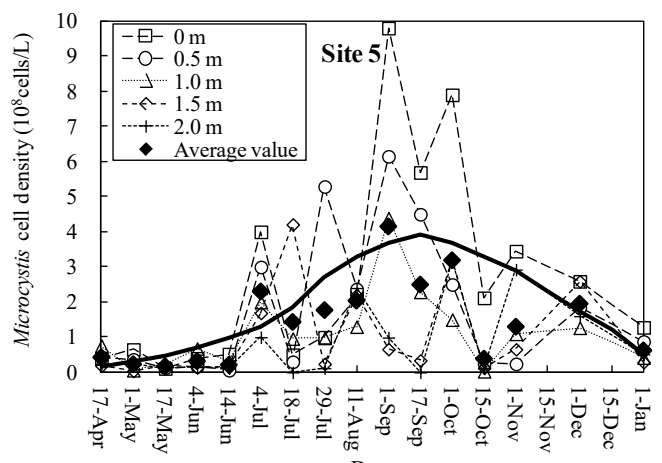

45

46

47
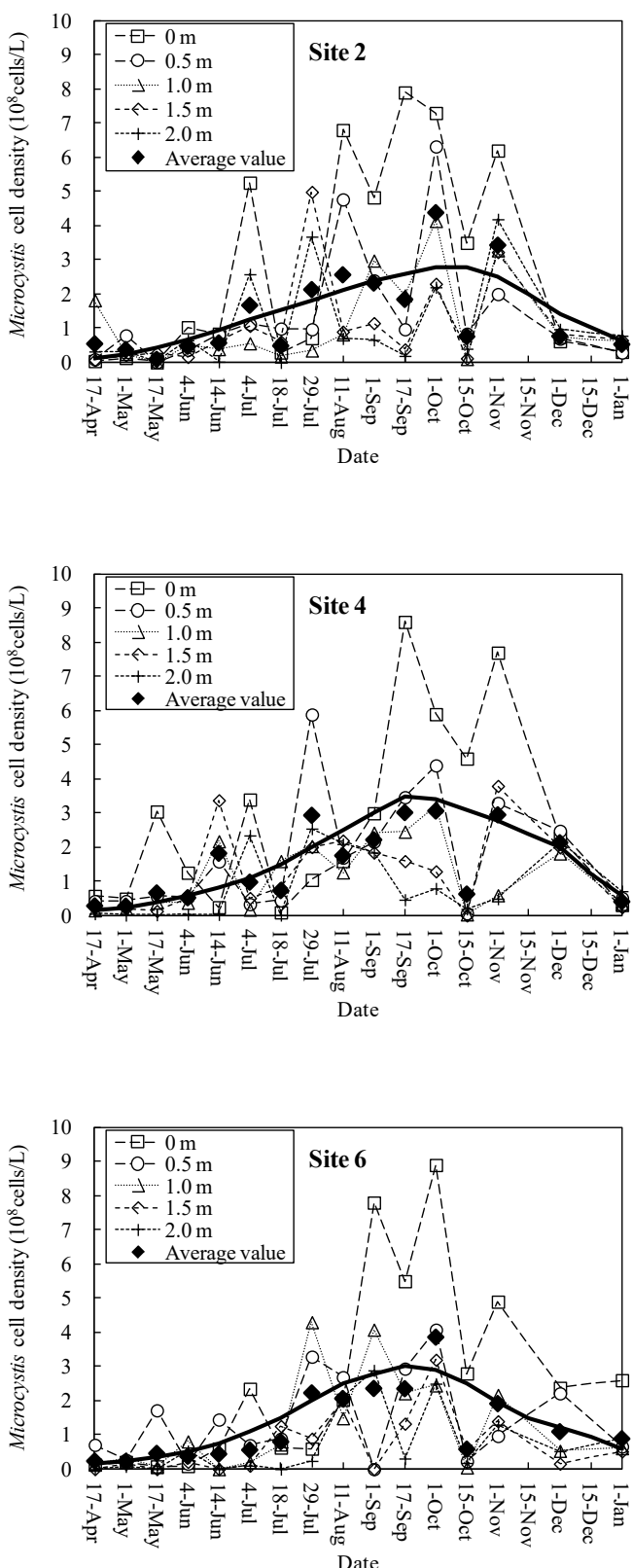

[Fig. 4] 

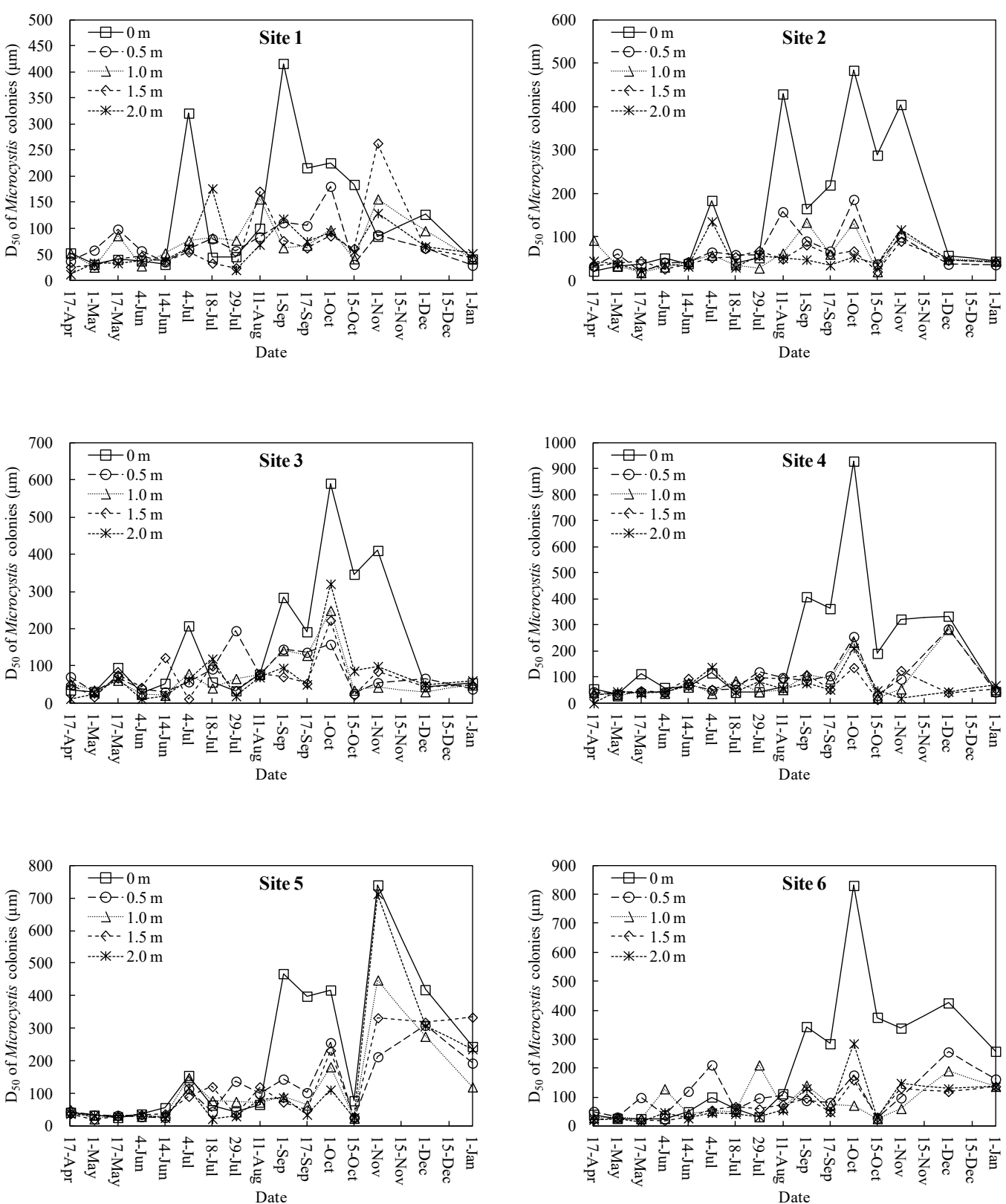

51

[Fig. 5] 


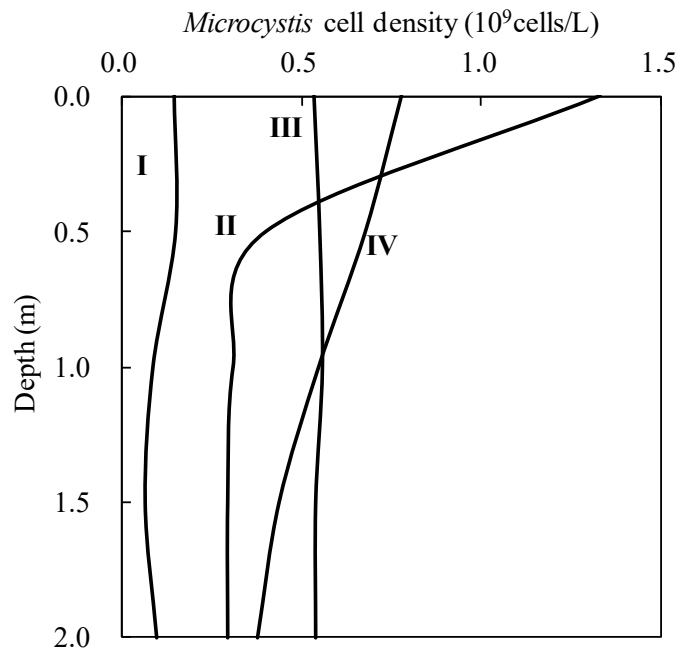

[Fig. 6a]

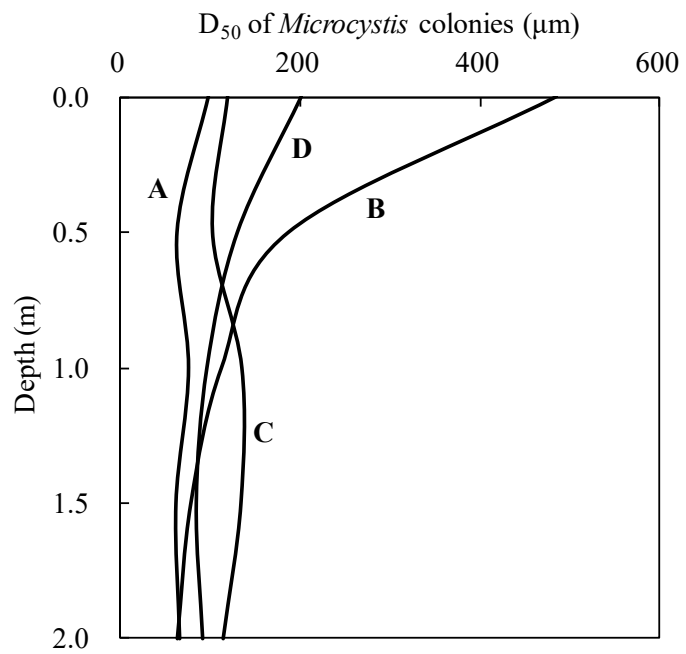

60

[Fig. 6b]

62

63

64

65 

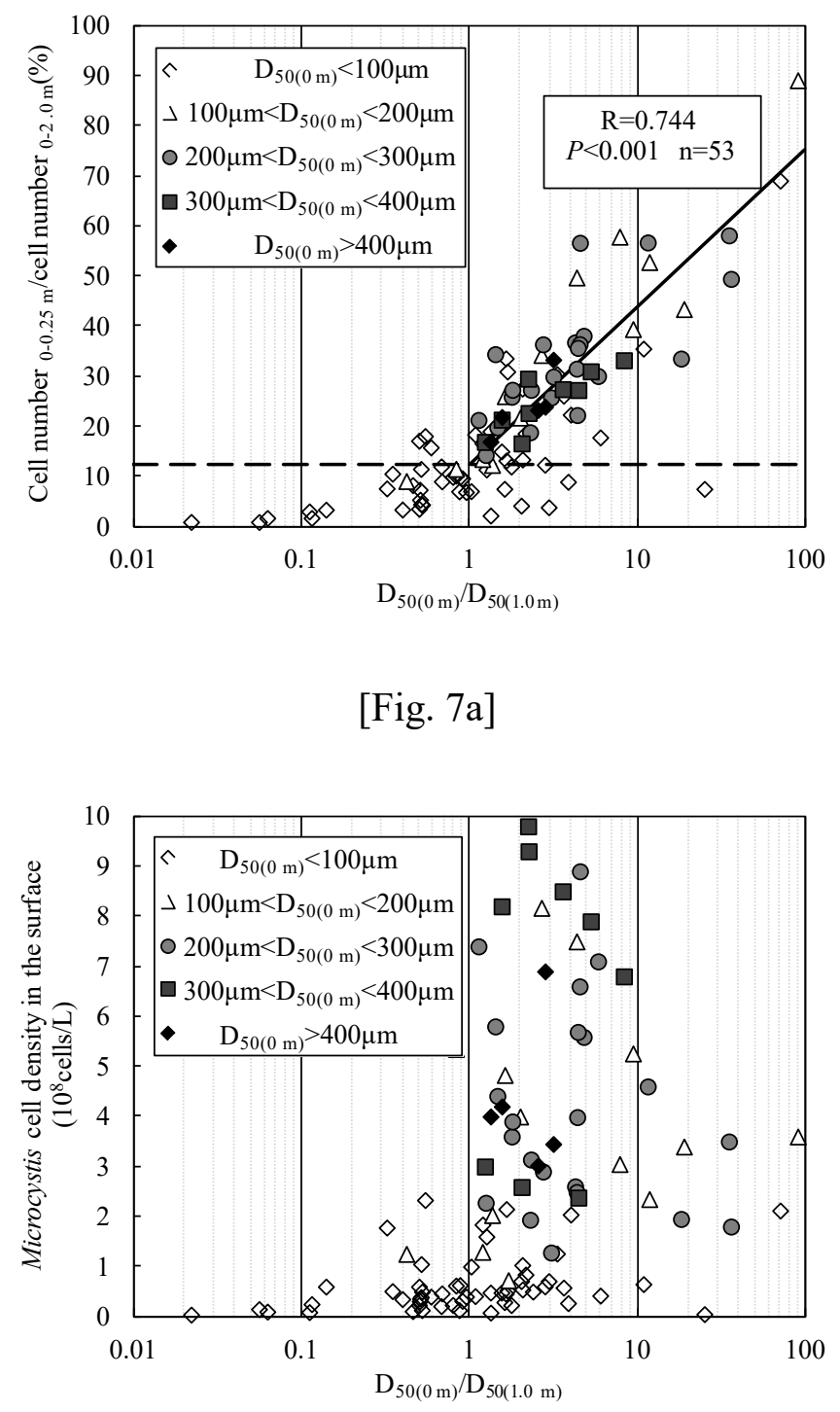




[Fig. 8] 